\title{
IMIDACLOPRID TOXICITY: EFFECTS ON THE CLASTOGENIC RESPONSE OF CARP (CYPRINUS CARPIO) FRY
}

\author{
ISPIR, U. ${ }^{1}-$ OZCAN, M. ${ }^{2 *}$ \\ ${ }^{1}$ Turgut Ozal University, Doğanşehir Vahap Küçük Vocational School, Department of \\ Aquaculture, Malatya 44210, Turkey \\ ${ }^{2}$ Kahramanmaras Sütçü Imam University, Agriculture Faculty, Department of Fisheries, \\ Kahramanmaras 46040, Turkey \\ ${ }^{*}$ Corresponding author \\ e-mail: mikailozcan@ksu.edu.tr; phone: +90-344-300-2097; fax: +90-344-300-2002
}

(Received $31^{\text {st }}$ Mar 2020; accepted $20^{\text {th }}$ Sep 2021)

\begin{abstract}
The article aimed to determine the effects of different doses of Imidacloprid on carp (Cyprinus carpio) fries, in order to determine whether their response could be used for the bioindication of the substance in aquatic environments in Turkey. The fish (weight $0.34 \pm 0.03 \mathrm{~g}$, total length $2.97 \pm 0.21$ $\mathrm{cm}$ ) were subjected to 2.8 and $5.6 \mathrm{mg} / \mathrm{l}$ of Imidacloprid concentration for 96 and $168 \mathrm{~h}$. A drop of blood from the caudal vein of carp was obtained and smeared on clean dry slide. Micronucleus (MN) and nuclear abnormality (NAs) analysis were carried out on erythrocytes. The frequency of micronucleus and nuclear abnormality observed varied significantly among the treated individuals $(\mathrm{p}<0.05)$. Imidacloprid led to negative alterations in the MN and NAs.
\end{abstract}

Keywords: carp, Cyprinus carpio, Imidacloprid, micronucleus, nuclear abnormality

\section{Introduction}

The environmental mutagens have been classified into three groups, such as, living, physical and chemical mutagens (Manna, 1982, 1983). The consequences of these pollutions on fish and shellfish have been studied by toxicologists. The exploratory, research in this field has identified it as an important environmental problem, all over the world. The effectiveness of these chemicals on the hereditary components of living organisms were categorised in genetic toxicology (Bickham et al., 2000; Iturburu et al., 2017). Brusick (1980) reported that even if many toxic substances damage the genetic material in nonspecific manner, the effect of these agents are highly specific on nucleic' acid. Hence these are capable of producing harmful effect at sublethal level.

The Imidacloprid can persist in soil, with 7-353 days for thiamethoxam and a halflife (28 - 1250 days) of neonicotinoids highly variable which varies greatly among soil type and other factors, (Goulson, 2013; Ansoar-Rodríguez et al., 2015). Also, depending on soil and rainfall conditions, $2.4 \%$ to nearly $80 \%$ of the mass of neonicotinoids (including Imidacloprid) could make their way into water bodies (Kurwadkar et al., 2013; Ansoar-Rodríguez et al., 2015; Bonmatin et al., 2015). Due to its presence in various environments, inhabited by large numbers of organisms, toxicological studies are extremely important. Thus, the use of living organisms (bioindicator), capable of somehow indicating the presence of stresses generated by environmental pollutants (Carneiro and Takayanagui, 2009; Abdel-Mohsien and Mahmoud, 2015), is one way to monitor the negative effects in the environment. Due to the presence of significant levels that have been detected in water, it is very 
important to conduct studies on the effects of Imidacloprid on aquatic organisms as bioindicators. Fish are widely to this end because their capacity to accumulate contaminants and show physiological, biochemical, histological or differentiated cell response (Fontanetti et al., 2012). These organisms may indicate variations in tolerance to environmental conditions created by the use of pesticides, including genetic change, which makes them excellent indicators with a high application for monitoring environmental genotoxicity (Yohannes et al., 2014).

The micronucleus (MN) assay has been used as a measure of genotoxicity in fish under laboratory and field conditions. The formation of nuclear abnormalities (NAs) such as lobed, blebbed, and notched nuclei described by several authors have been reported in fish erythrocytes as a consequence of exposure to environmental and chemical contaminants with cytotoxic, genotoxic, mutagenic or carcinogenic activity. The micronucleus test in fish has the potential to detect clastogenic and aneugenic effects of environmental agents in aqueous media. Because teleost erythrocytes are nucleated, MN have been scored in fish erythrocytes as a measure of clastogenic activity (Heddle et al., 1983; Al-Sabti and Metcalfe, 1995; Fenech et al., 2003; Machado Da Rocha et al., 2009).

Paralichthys olivaceus, in vitro cytotoxicity median inhibitory concentrations of $38.5 \mathrm{mg} / \mathrm{L}$ to $41.9 \mathrm{mg} / \mathrm{L}$ of technical imidacloprid were reported, whereas other species like Oncorhynchus mykiss and Cyprinus carpio presented 96-h LC50 values of $211 \mathrm{mg} / \mathrm{L}$ and $280 \mathrm{mg} / \mathrm{L}$, respectively. Other negative effects, like the alteration of the neurobehavioral function in early-life and adult zebrafish (Crosby et al., 2015) or the stress syndrome in juvenile Oryzias latipes (Sanchez Bayo and Goka, 2005), have been described. Other vertebrates also suffer imidacloprid effects. For example, increased DNA damage in human peripheral blood lymphocytes exposed in vitro to 20 $\mathrm{mM}$ imidacloprid (5 mg/L) have been reported (Costa et al., 2009).

There was no published report on clastogenic effect of Imidacloprid on carp fry. Based on the observations from literature survey, it was investigated to study the toxic effect of Imidacloprid on erythrocytes of carp, C. carpio.

\section{Materials and Methods}

\section{Fish and chemical supply}

Fish samples, weighing $0.34 \pm 0.03 \mathrm{~g}$, were obtained from the Keban Fish Breeding Unit of IX. Region Directorate, the State Hydraulic Works in Turkey. They were brought to the laboratory and acclimated to laboratory conditions for 14 days. Water temperature in the tank was maintained at $24.0 \pm 1.0^{\circ} \mathrm{C}$ using a heater. Fishes were fed with pellet feeds during acclimating. Fish were fed ad libitum with a commercial feed throughout the experiments. Fish were stocked in 3 groups ( 25 fish/per group) in the tanks supplied.

The first group was maintained in tap water as a control group. The fish in group 2 and 3 were exposed to 2.8 and $5.6 \mathrm{mg} / \mathrm{l}$ of Imidacloprid ( $\mathrm{N}-\{1-[(6$-chloro-3-pyridyl) methyl]-4,5-dihydroimidazol-2-yl $\}$ nitramide) concentration for 96 and $168 \mathrm{~h}$ (7 days). The entire experiment was repeated two independent times; each replicate for each group contained twenty-five fish, for a total of 150 fish. At the $96 \mathrm{~h}$ and $168 \mathrm{~h}$ of the test, the fish were anaesthetized in an anaesthetic matter ( $50 \mathrm{ppm}$, benzocaine) and a drop blood was taken from the caudal vein. Water quality parameters were monitored daily for each tank. 


\section{Micronucleus assay}

The slides were prepared by smearing one drop of blood on clean microscopic slides, fixed in methanol for $10 \mathrm{~min}$ and left to air-dry at room temperature and finally stained with $5 \%$ Giemsa in Sorenson buffer $(\mathrm{pH}$ 6.9) for 20 min. A total of 1000 erythrocytes were examined for each specimen under the light microscope. For the scoring of micronuclei, the following criteria were adopted from Fenech et al. (2003). The diameter of the MN should be less than one-third of the main nucleus. MN should be separated from or marginally overlap with main nucleus as long as there is clear identification of the nuclear boundary. MN should have similar staining as the main nucleus.

\section{Statistical analysis}

The one-way analysis of variance (ANOVA), Duncan's Multiple Range Test was employed to compare the mean differences in $\mathrm{MN}$ frequency between control and different exposure periods and, in between successive exposure periods.

\section{Results}

Imidacloprid exposure elicited hyperactivity characterized by opercula movement, erratic swimming, loss of equilibrium, hanging in the water vertically and gasping for air. However, no fish died after the $168 \mathrm{~h}$ period of exposure to different Imidacloprid doses.

Results of micronucleus assays with carp are shown in Tables 1, 2 and Figures 1, 2. In the $2.8 \mathrm{mg} / \mathrm{L}$ Imidacloprid group, the micronuclei cell number were not significantly different $(\mathrm{p}>0.05)$. As shown in the figure, Imidacloprid treatment significantly increased the micronucleus frequency in blood $(\mathrm{P}<0.05)$ in $5.6 \mathrm{mg} / \mathrm{L}$ treatment group. For the concentration of $5.6 \mathrm{mg} / \mathrm{L}$ Imidacloprid, the number of micronuclei cell was significantly higher than control after exposure of $168 \mathrm{~h}$, whereas the micronuclei abnormalities did not show any increase in relation to the control group up to 96 hours (Fig. 3). The number of nuclear abnormality (NA) moderate increased both $96 \mathrm{~h}$ and $168 \mathrm{~h}$ in $5.8 \mathrm{mg} / \mathrm{L}$ Imidacloprid group.

Table 1. Mean values of micronuclei frequencies in blood of fishes treaed with Imidacloprid

\begin{tabular}{c|c|c}
\hline & $\mathbf{9 6 h}$ & $\mathbf{1 6 8 h}$ \\
\hline Control & $1.72 \pm 0.12$ & $1.74 \pm 0.11$ \\
$\mathbf{2 . 8} \mathbf{~ m g / L}$ & $1.69 \pm 0.09$ & $1.73 \pm 0.13$ \\
$\mathbf{5 . 6} \mathbf{~} \mathbf{L} / \mathbf{L}$ & $1.93 \pm 0.19^{\mathrm{a}, \mathrm{b}}$ & $2.28 \pm 0.20^{\mathrm{a}, \mathrm{b}}$ \\
\hline
\end{tabular}

Table 2. Mean values of binuclei frequencies in blood of fishes treaed with Imidacloprid

\begin{tabular}{c|c|c}
\hline & $\mathbf{9 6 h}$ & $\mathbf{1 6 8 h}$ \\
\hline Control & $0.11 \pm 0.01$ & $0.14 \pm 0.02$ \\
$\mathbf{2 . 8} \mathbf{~ m g / L}$ & $0.09 \pm 0.01$ & $0.13 \pm 0.03$ \\
$\mathbf{5 . 6} \mathbf{~ m g / L}$ & $0.12 \pm 0.02$ & $0.14 \pm 0.02$ \\
\hline
\end{tabular}




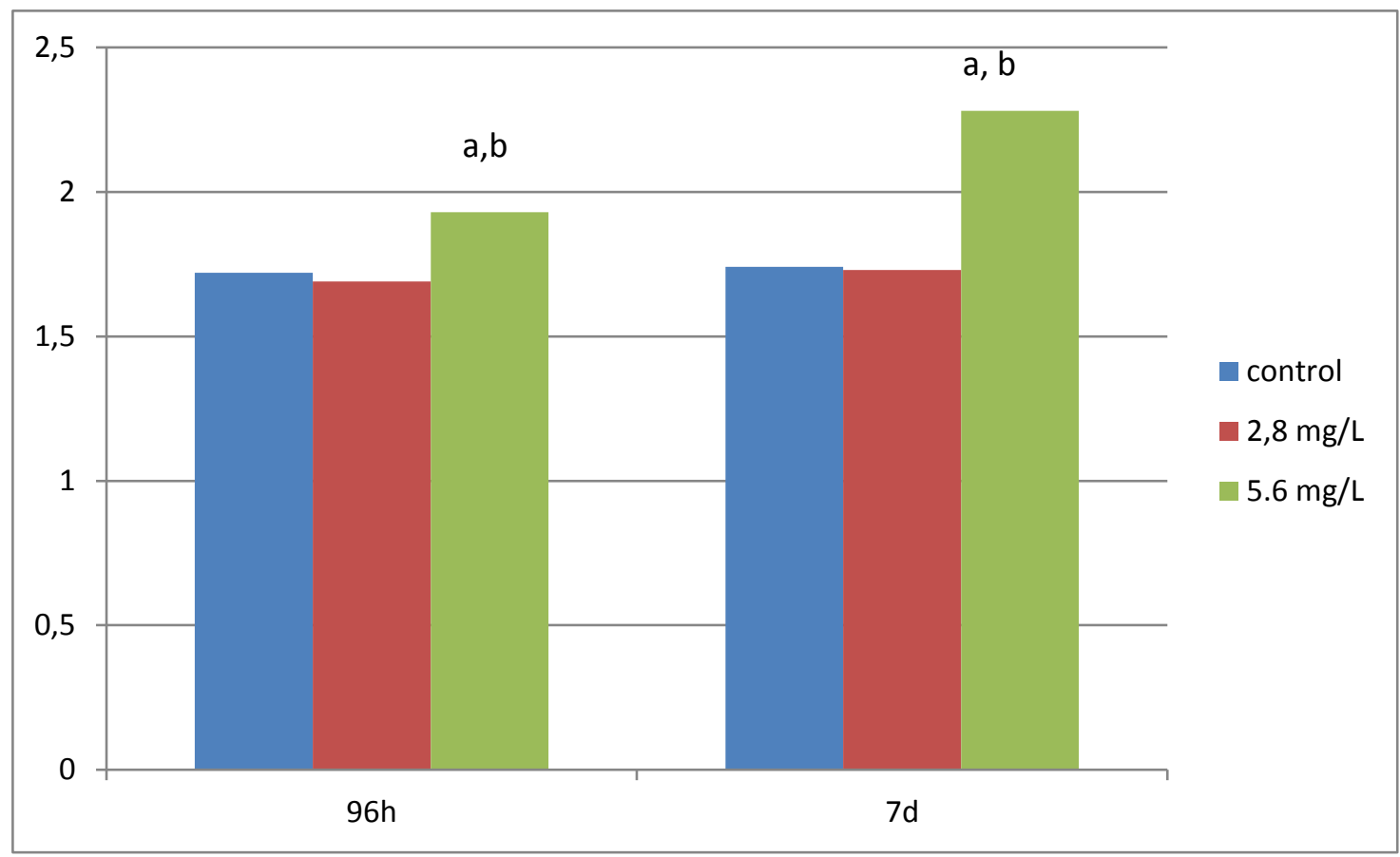

Figure 1. The erythrocytes from carp exposed to imidacloprid. (A) normal erythrocytes (B) micronucleus

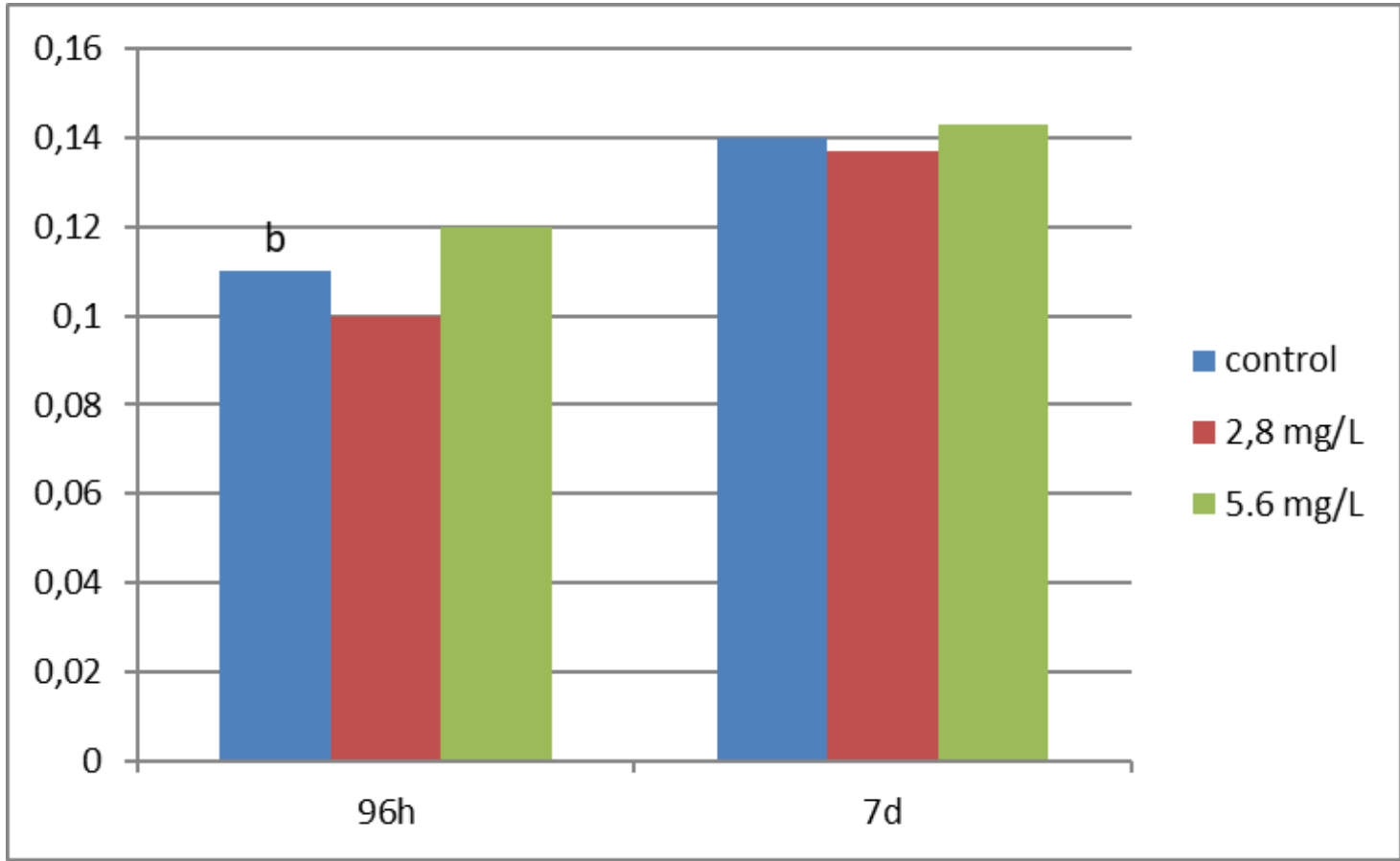

Figure 2. Mean values of binuclei frequencies in blood of fishes treaed with Imidacloprid 


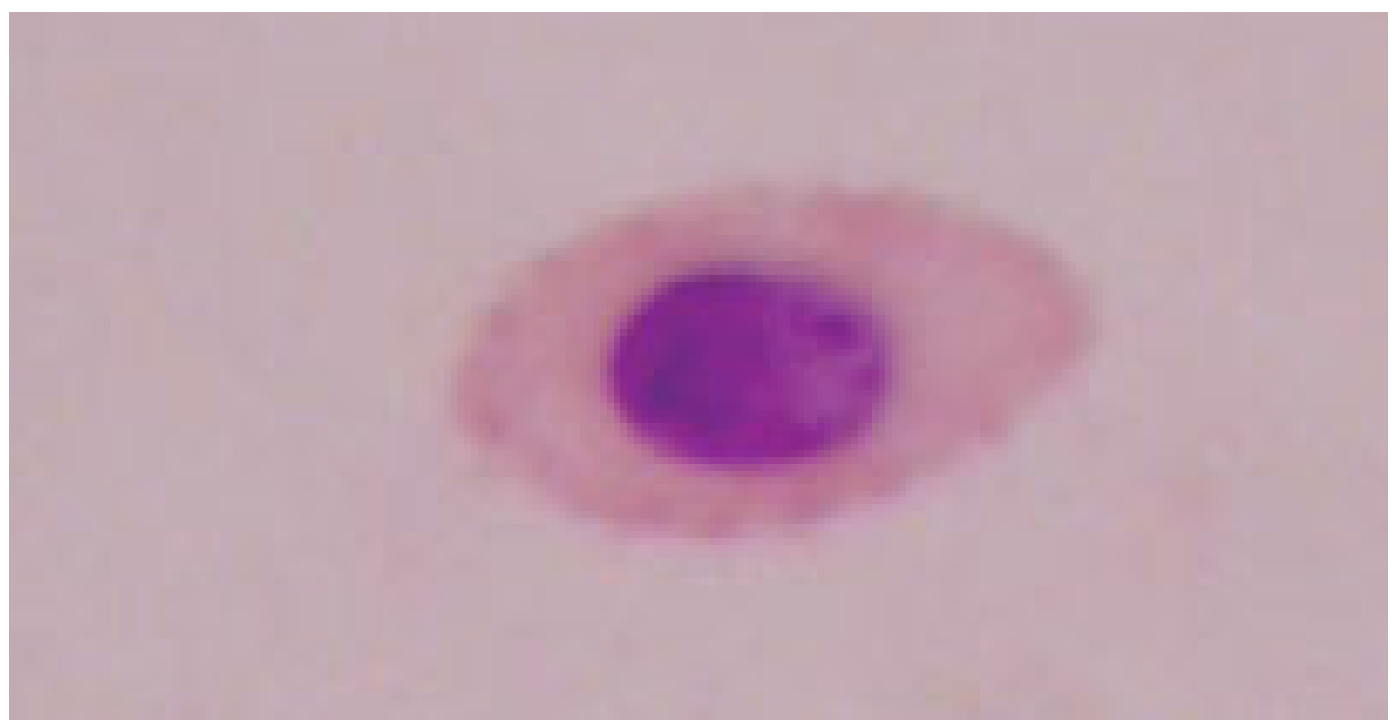

(A)

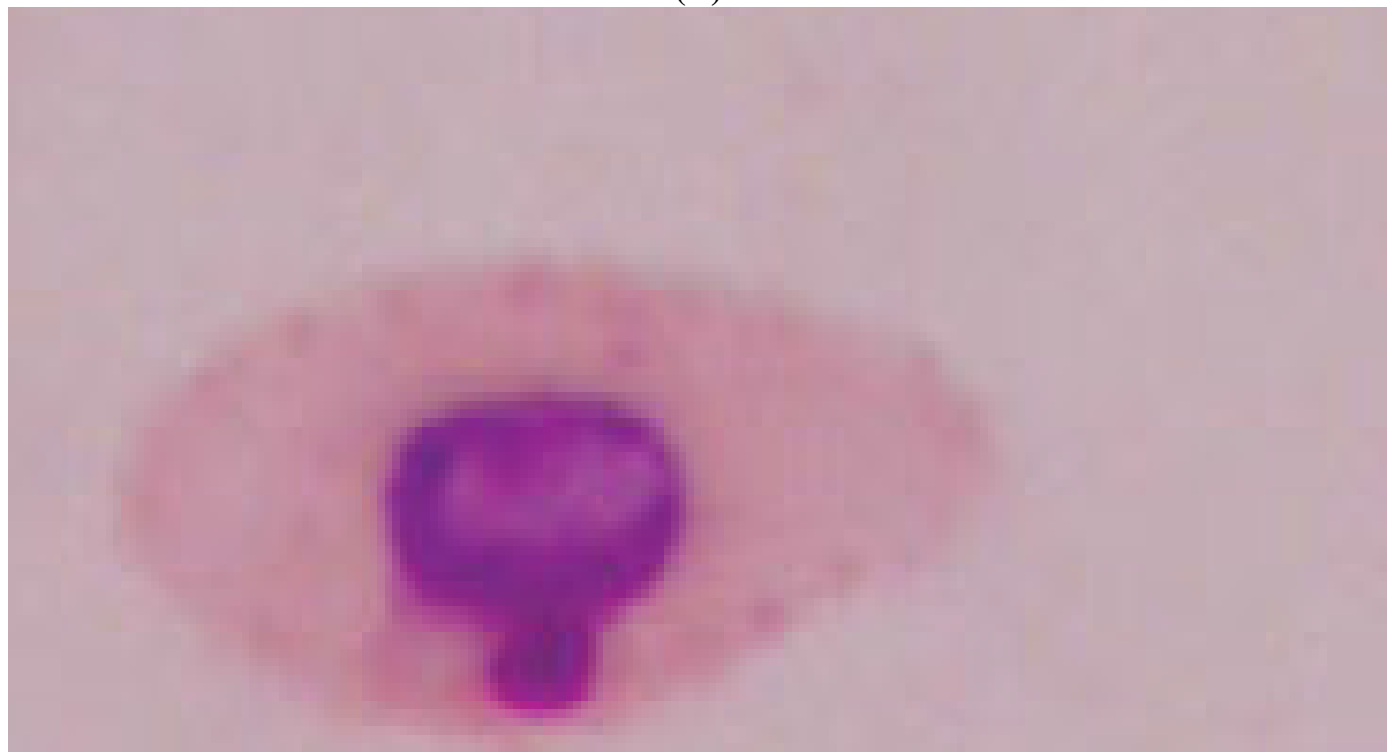

(B)

Figure 3. The erythrocytes from carp exposed to imidacloprid. (A) normal erythrocytes (B) micronucleus

\section{Discussion}

In the commercial formulation bioassay all fish exposed to $10000 \mathrm{mg} / \mathrm{L}$ İmidacloprid died after $3 \mathrm{~h}$ (Iturburu et al., 2017). In this study, Imidacloprid exposure elicited hyperactivity characterized by opercula movement, erratic swimming, loss of equilibrium, hanging in the water vertically and gasping for air. However, no fish died after the $168 \mathrm{~h}$ period of exposure to different Imidacloprid doses.

This study, Imidacloprid caused a dose-dependent increase in the frequency of $\mathrm{MN}$ and other NAs, which was statistically significant $(\mathrm{p}<0.05)$ in the highest concentration evaluated $(5.6 \mathrm{mg} / \mathrm{L})$ compared to the control (Tables 1, 2 and Figs. 1, 2). The results obtained in this study corroborate other pesticide studies using different species of fish, such as the evaluation of Imidacloprid (1-[(6-chloro-3-pyridinylmethyl]-N-nitro-2- 
imidazolidinimine; $\mathrm{CASN}^{\circ} 138261-41-3$; molecular formula $\mathrm{C} 9 \mathrm{H} 10 \mathrm{ClN} 5 \mathrm{O} 2$ ), Aficida ${ }^{\circledR}$ and Endosulfan insecticides in fish erythrocytes from Oreochromis niloticus (Perciformes, Cichlidae), Cnesterodon decemmaculatus (Poeciliidae) and Carassius carassius (Cyprinidae) by the MN test (Candioti et al., 2010; Dar et al., 2015; AnsoarRodríguez et al., 2015). These studies demonstrate the effectiveness of fish and the MN test as a model for the biomonitoring of aquatic ecosystems that may be affected by pesticides.

At $100 \mathrm{mg} / \mathrm{L}$ and $1000 \mathrm{mg} / \mathrm{L}$ the imidacloprid micronucleus frequency was significantly higher than its negative control. Conversely, in the active ingredient bioassay the micronucleus frequency was significantly higher at $1000 \mathrm{mg} / \mathrm{L}$ imidacloprid in relation to its negative control (Iturburu et al., 2017). This study, for the concentration of $5.6 \mathrm{mg} / \mathrm{L}$ Imidacloprid, the number of micronuclei cell was significantly higher than control after exposure of $168 \mathrm{~h}$, whereas the micronuclei abnormalities did not show any increase in relation to the control group up to 96 hours (Fig. 3). The number of nuclear abnormality (NA) moderate increased both $96 \mathrm{~h}$ and $168 \mathrm{~h}$ in $5.8 \mathrm{mg} / \mathrm{L}$ Imidacloprid group.

\section{Conclusion}

Considering the genotoxic effects of Imidacloprid on C. carpio as obtained in this study by $\mathrm{MN}$, there is serious apprehension about the potential danger of this drug to aquatic organisms. However, detailed studies using other assays having different end points may be needed to confirm the mutagenic and genotoxic status of the Imidacloprid and further explore the mechanism and interactions with the DNA metabolism in different aquatic organisms, especially fish.

Acknowledgment. This work was presented as an oral presentation at the $2^{\text {nd }}$ International Conference on Civil and Environmental Engineering (Cappadocia-2017), May 8 - 10, 2017, Nevşehir, Turkey.

Ethical Approval. All animal studies were approved by the Animal Ethics Committee of Kahramanmaraş Sütçü Imam University, Faculty of Agriculture (KSÜZİRHADYEK) and Research Institute (Protocol number: 2016/5-1).

\section{REFERENCES}

[1] Abdel-Mohsien, H. S., Mahmoud, M. A. M. (2015): Accumulation of Some Heavy Metals in Oreochromis niloticus from the Nile in Egypt: Potential Hazards to Fish and Consumers. - Journal of Environmental Protection 6: 1003-1013.

[2] Al-Sabti, K. C. D. (1995): Metcalfe. Fish micronuclei for assessing genotoxicity in water. - Mutat. Res. 343: 121-135.

[3] Ansoar-Rodríguez, Y., Christofoletti, C. A., Marcato, A. C., Correia, J. E., Bueno, O. C., Malaspina, O., Fontanetti, C. S. (2015): Genotoxic Potential of the Insecticide Imidacloprid in a Non-Target Organism (Oreochromis niloticus-Pisces). - Journal of Environmental Protection 6: 1360-1367.

[4] Bickham, J. W., Sandhu, S., Hebert, P. D. N., Chikhi, L., Athwal, R. (2000): Effects of chemical contaminants on genetic diversity in natural populations: Implications for biomonitoring and ecotoxicology. - Mutat Res 463: 33-51.

[5] Bonmatin, J. M., Giorio, C., Girolami, V., Goulson, D., Kreutzweiser, D. P., Krupke, C., Liess, M., Long, E., Marzaro, M., Mitchell, E. A. D., Noome, D. A., Simon-Delso, N., 
Tapparo, A. (2015): Environmental fate and exposure; neonicotinoids and fipronil. Environ Sci Pollut Res 22: 35-67.

[6] Brusick, D. J. (1980): Principles of genetic toxicology (First edition). - Plenum Press, New York, 279p.

[7] Candioti, J. V., Soloneski, S., Larramendy, M. L. (2010): Genotoxic and Cytotoxic Effects of the Formulated Insecticide Aficida ${ }^{\circledR}$ on Cnesterodon decemmaculatus (Jenyns, 1842) (Pisces: Poeciliidae). - Mutation Research 703: 180-186.

[8] Carneiro, R. M. A., Takayanagui, A. M. M. (2009): Estudos sobre bioindicadores vegetais e poluição atmosférica por meio de revisão sistemática da literatura. - Revista Brasileira de Ciências Ambientais 13: 26-44.

[9] Costa, C., Silvari, V., Melchinib, A., Catania, S., Heffronc, J. J., Trovato, A., De Pasquale, R. (2009): Genotoxicity of imidacloprid in relation to metabolic activation and composition of the commercial product. - Mutat Res 672(1): 40-44.

[10] Crosby, E. B., Bailey, J. M., Oliveri, A. N., Levin, E. D. (2015): Neurobehavioral impairments caused by developmental imidacloprid exposure in zebrafish. - Neurotoxicol Teratol 49: 81-90.

[11] Dar, S. A., Yousuf, A. R., Balkhi, M. H., Ganai, F. A., Bhat, F. A. (2015): Assessment of Endosulfan Induced Genotoxicity and Mutagenicity Manifested by Oxidative Stress Pathways in Freshwater Cyprinid Fish Crucian Carp (Carassius carassius L.). Chemosphere 120: 273-283.

[12] Fenech, M., Chang, W. P., Kirsch-Volders, M., Holland, N., Bonassi, S., Zeiger, E. (2003): HUMN project: Detailed description of the scoring criteria for the cytokinesisblock micronucleus assay using isolated human lymphocyte cultures. - Mutat. Res. 534: 65-75.

[13] Fontanetti, C. S., Souza, T. S., Christofoletti, C. A. (2012): Sustainable Water Management in the Tropics and Subtropics-and Case Studies in Brazil. - The Role of Biomonitoring in the Quality Assessment of Water Resources 3: 975-1005.

[14] Goulson, D. (2013): Review: An Overview of the Environmental Risks Posed by Neonicotinoid Insecticides. - Journal of Applied Ecology 50: 977-987.

[15] Heddle, J. A., Hite, M., Jrkhart, B., Macgregor, J., Salamone, M. (1983): The induction of micronuclei as a measure of genotoxicity. - Mutat. Res. 123: 61-118.

[16] Iturburu, F. G., Zömısch, M., Panzerı, A. M., Crupkın, A. C., Contardo-Jara, V., Pflugmacher, S., Menone, M. L. (2017): Uptake, distribution in different tissues, and genotoxicity of imidacloprid in the freshwater fish Australoheros facetus. Environmental Toxicology and Chemistry 36(3): 699-708.

[17] Kurwadkar, S. T., Dewinne, D., Wheat, R., McGaha, D. G., Mitchell, F. L. (2013): Time Dependent Sorption Behavior of Dinotefuran, Imidacloprid and Thiamethoxam. - Journal of Environmental Science and Health (Part B) 48: 237-242.

[18] Machado Da Rocha, C. A., Dos Santos, R. A., De Oliveira Bahia, M., Da Cunha, L. A., Ribeiro, H. F., Burbano, R. M. R. (2009): The Micronucleus Assay in Fish Species as an Important Tool for Xenobiotic Exposure Risk Assessment - A Brief Review and an Example Using Neotropical Fish Exposed to Methylmercury. - Reviews in Fisheries Science 17(4): 478-484.

[19] Manna, G. K. (1982): The new horizon of mutagenesis. - Curr. Sci. 51: 1087-1093.

[20] Manna, G. K. (1983): Cytogenetics studies on fishes and amphibia. - In: Genetical Research in India, XV Intern. Congr. Genet. New Delhi, India, 12-21. ICAR, pp. 244273.

[21] Sanchez Bayo, F., Goka, K. (2005): Unexpected effects of zinc pyrithione and imidacloprid on Japanese medaka fish (Oryzias latipes). - Aquat Toxicol 74: 285-293.

[22] Yohannes, Y. B., Ikenaka, Y., Saengtienchai, A., Watanabe, K. P., Nakayama, M. M., Ishizuka, M. (2014): Concentrations and Human Health Risk Assessment of Organochlorine Pesticides in Edible Fish Species from a Rift Valley Lake-Lake Ziway, Ethiopia. - Ecotoxicology and Environmental Safe 106: 95-101. 